\title{
Decision Support System for "Buleleng Cerdas" Program Social Fund Recipient Candidates with Analytical Hierarchy Process (AHP) and Simple Additive Weighting (SAW) Method
}

\author{
Aini Aidilah Fitri ${ }^{1}$, I Made Ardwi Pradnyana², I Gede Mahendra \\ Darmawiguna $^{3}$ \\ 1,2,3 Informatics Education Departement, Universitas Pendidikan Ganesha Singaraja, Indonesia \\ Email: ${ }^{1}$ ainiaidilahfitri29@gmail.com, ${ }^{2}$ ardwi.pradnyana@undiksha.ac.id, \\ ${ }^{3}$ mahendra.darmawiguna@undiksha.ac.id
}

\begin{abstract}
BAZNAS in Buleleng Regency has a problem program "Buleleng Cerdas". The problems are to make a decision to choose prospective scholarship recipients. The program activities include Student Assistance, One Family One Scholar, and Student Assistance with Achievement. The problems that arise because the selection of the prospective recipients are still manual and the assessment of the final results obtained is relatively long, still difficult to identify prospective recipients who are eligible in accordance with the existing quota, because the candidates Scholarship recipients are spread in the Buleleng region for private and public schools. The purpose of this research is to develop a Decision Support System for "Buleleng Cerdas" Program Social fund Recipient Candidates with AHP and SAW Method and to know the responsiveness of users. This system is supported by a method of decision making, namely the AHP method which is used to find the weights in each criterion, and the ranking calculation with the SAW method. For the testing process, four test process stages are performed: (1) black box test, (2) white box test (3) test UEQ percentage is positive impression \& SUS percentage is $93 \%$, (4) suitability testing of manual calculations on the system is appropriate.
\end{abstract}

Keywords: Decision Support System, AHP, SAW, Buleleng Cerdas, BAZNAS

\section{INTRODUCTION}

The National Zakat Agency in the Indonesian abbreviation Badan Amil Zakat Nasional (BAZNAS) is the official and the only body established by the government based on the Republic of Indonesia Presidential Decree No. 8 of 2001 which has the duty and function of collecting and distributing zakat, infaq and alms/ sadaqoh (ZIS) at the national level. The birth of the Act (Act) Number 23 of 2011 concerning the Management of Zakat increasingly confirms the role of BAZNAS as an institution authorized to carry out zakat management nationally.

Related to the development of technology and the need for information that is fast, accurate and transparent. The National Zakat Agency (BAZNAS) has aspirations to realize this. The existence of the program from the annual budget plan was formed from zakat fitrah and zakat mal (gold) of all Muslim communities in 
Buleleng regency that were collected. The Annual Budget Plan has several programs such as: Buleleng Cerdas, Buleleng Sehat, Buleleng Taqwa, Buleleng Peduli and Buleleng Makmur.

"Buleleng Cerdas" program that had been running from 2016 was one of the 5 programs planned. The "Buleleng cerdas" activity program includes: Student Assistance, One Family One Scholar, and Student Assistance with Achievement in Buleleng Regency.

There are problems that can be found in administering of these programs such as annual budget plan. This problem arises year by year because the selection of the prospective recipients is still manual which causes the final results obtained to make decisions relatively long. According to National Zakat Agency itself, it is still difficult to identify prospective recipients who are entitled to receive in accordance with the quota that has been determined. The difficulty of the recipient identification is occured because prospective scholarship recipients are scattered in the Buleleng area which is attended by all primary, junior high and high school schools with a number of private and state status. From these elections each year there is an increase in potential recipients. The cause of the problem is the absence of a clear weighting assessment in each criterion, then the problems that arise when there is the same final value among scholarship recipients to fill the quota provided. It needed for information that fast, accurate, transparent and assisted by a technology. So, a system as making a decision aims to facilitate the performance of the National Zakat Agency quickly and efficiently. It can be conducted by developing decision support system.

Decision Support System (DSS) is an interactive, flexible, easy to adapt (adaptable) Computer Based Information System specifically developed to support the completion of unstructured problems to improve decision making [1]. The existence of this decision support system can certainly provide information in order to make better decisions.

From the analysis of previous research, there are studies that focus on only one method namely AHP, Fuzzy AHP and SAW as the research conducted by [2] [3] and [4]. In addition there are studies that combine the fuzzy AHP and SAW methods conducted by [1] and the research compares the two methods, namely the AHP and SAW methods conducted by [5]. Therefore, in contrast to the research that will be carried out by researchers that combines both methods, the AHP method is used to find the weight of each criterion and the use of SAW aims to rank prospective recipients. In addition, this research aims to strengthen previous research that if these two methods are combined can be used in the selection of recipients of social funds "Buleleng Cerdas" scholarships. In addition, this study adds different criteria. The criteria of the Student Assistance Recipients are the Fakir, Poor Parents of income, parent's business/work, dependents of parents and debt/ gharimin. Then Recipients of Achievement Students have the same criteria as Recipients, only have two more criteria, namely Academic Achievement and 
Non-Academic Achievement. Whereas, for One Family One Scholarship Recipients have the same criteria as Achievement Recipients, but have one additional criterion that is No Bachelor in One Family. In developing this system researchers use the PHP programming language with Framework Laravel, MySQL for database creation and web page layout design researchers using HTML5, CSS3, Bootstrap Framework, and Javascript.

\section{METHODS}

In designing and developing research decision support systems for prospective recipients of social funding programs "Buleleng Cerdas". Researchers used two methods from MADM including using AHP method and SAW. AHP was originally designed to solve complex multi-criteria decision problems (Saaty, 1980) in [6]. The AHP method is often used as a problem-solving method compared to other methods for the following reasons:

1) The hierarchical structure, as a consequence of the selected criteria, reaches the deepest subcriteria.

2) Taking into account the validity up to the tolerance limit for inconsistency of various criteria and alternatives chosen by decision makers.

The AHP method has a basic principle according to [5] namely Decomposition, Comparative judgment, Synthesis of priority and Logical Consistency. While the SAW method is to find the sum weighted from the performance rating on each alternative on all attributes. according to [7] SAW is a multi-attribute procedure based on the weighted addition concept.

From the explanation of the two methods, it has different uses, namely AHP is used to find the weight/priority value of each criterion and SAW is used to rank alternatives from the assessment of criteria that have been done previously in the AHP method. In the design of this research development using Unifed Modeling Language (UML) modeling that is Use Case Diagram (UCD) and activity diagram.

The research method used is the type of research and development (Research and Development/R \& D) with the method or model of SDLC (System Development Life Cycle). The research method of SDLC uses the Linear Sequential Model/Waterfall Model. Waterfall Model describes a systematic and sequential approach to software developed. The following stages of the Waterfall Model are shown in Figure 1.

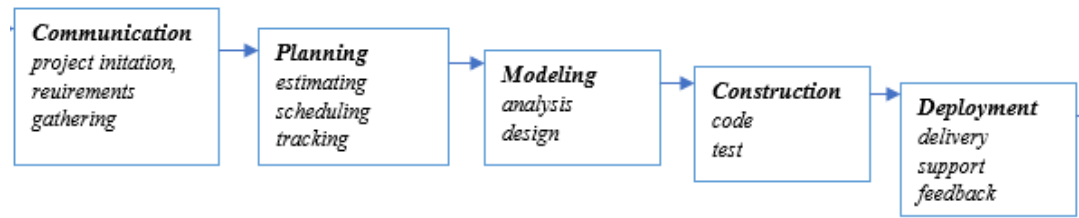

Figure 1. Waterfall model [8] 
There are five stages of in this waterfall model. First, communication stage is conducted by collecting information that can be used as material for making products. Second, planning stage explain the technical tasks performed. Third, modeling stage is required to design a system that helps in defining the overall system architecture. Fourth, the construction stage is conducted to code a design translator in a language that can be recognized by the computer. After coding, it will conduct a testing that aims to find errors in the system for repair later. The last stage is the deployment phase, which is the implementation phase of the stage that has been conducted before.

\section{RESULTS AND DISCUSSION}

The design of the Use Case Diagram is used for interaction between one or more actors with the system to be developed. Shown in Figure 2.

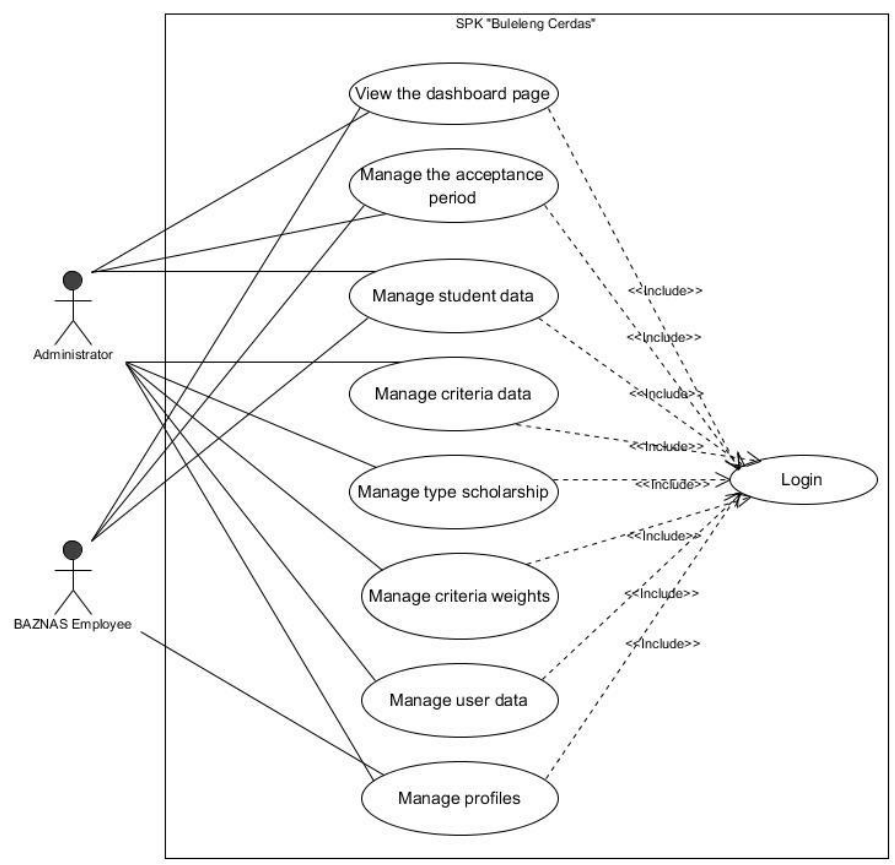

Figure 2. Use case diagram

From the use case diagram of each actor, the following is the system display implementation for administrators in the Figure 3. 


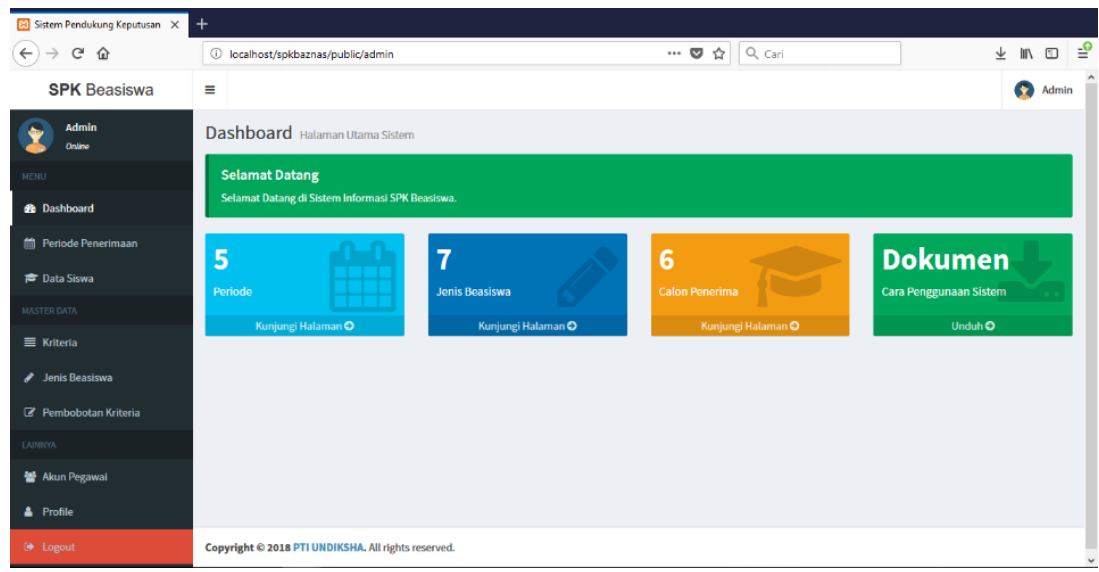

Figure 3. Implementation of the administrator interface display

While the system display for employees can only access some features in accordance with the designed use case diagram. Furthermore, the design of the calculations using the AHP and SAW methods can be seen in Figure 3.

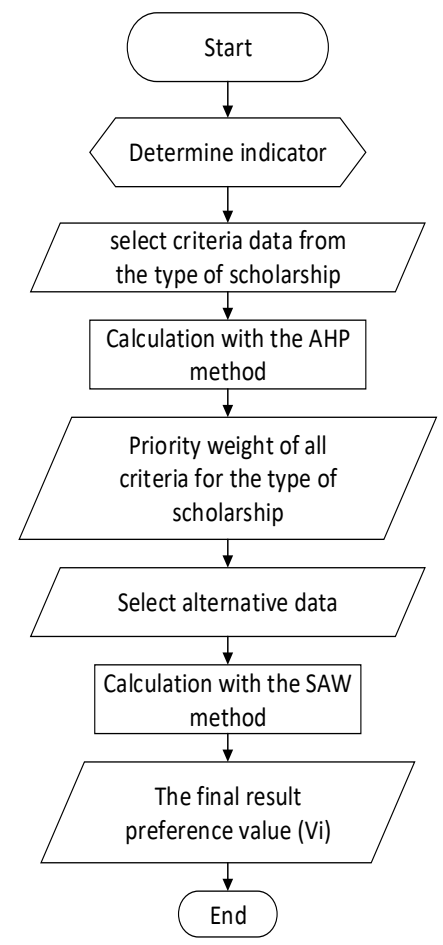

Figure 4. Flowchart of AHP and SAW calculations 
From the design of the flowchart. As for calculations with the AHP and SAW methods are explained as follows.

1) Determine the Pairwise Comparison Matrix

Pairwise comparation matrix shown in Table 1

Table 1. Pairwise comparison matrix

\begin{tabular}{clllllll}
\hline Criteria & FK & MK & HG & POT & TOT & UPOT \\
\hline Fakir (FK) & 1 & 3 & 3 & 5 & 7 & 7 \\
Poor(MK) & $1 / 3$ & 1 & 3 & 3 & 5 & 7 \\
Debt/ Gharimin (HG) & $1 / 3$ & $1 / 3$ & 1 & 3 & 5 & 5 \\
Parents of income (POT) & $1 / 5$ & $1 / 3$ & $1 / 3$ & 1 & 3 & 3 \\
Dependents of parent (TOT) & $1 / 7$ & $1 / 5$ & $1 / 5$ & $1 / 3$ & 1 & 3 \\
Parent's business/ work(UPOT) & $1 / 7$ & $1 / 7$ & $1 / 5$ & $1 / 3$ & $1 / 3$ & 1 \\
Total & 2,15 & 5,01 & 7,73 & 12,67 & 21,33 & 26,00 \\
\hline
\end{tabular}

2) Create a Work Value Matrix that produces criteria weight The work value matrix shown in Table 2

Table 2. Work value matrix that produces criteria weight

\begin{tabular}{ccccccccr}
\hline Criteria & FK & MK & HG & POT & TOT & UPOT & Total & Priority \\
\hline Fakir (FK) & 0,46 & 0,60 & 0,39 & 0,39 & 0,33 & 0,27 & 2,44 & 0,41 \\
Poor(MK) & 0,15 & 0,20 & 0,39 & 0,24 & 0,23 & 0,27 & 1,48 & 0,25 \\
$\begin{array}{c}\text { Debt/ Gharimin } \\
\text { (HG) }\end{array}$ & 0,15 & 0,07 & 0,13 & 0,24 & 0,23 & 0,19 & 1,01 & 0,17 \\
$\begin{array}{c}\text { Parents of income } \\
\text { (POT) }\end{array}$ & 0,09 & 0,07 & 0,04 & 0,08 & 0,14 & 0,12 & 0,54 & 0,09 \\
$\begin{array}{c}\text { Dependents of parent } \\
\quad \text { (TOT) }\end{array}$ & 0,07 & 0,04 & 0,03 & 0,03 & 0,05 & 0,12 & 0,32 & 0,05 \\
$\begin{array}{c}\text { Parent's business/ } \\
\text { work(UPOT) }\end{array}$ & 0,07 & 0,03 & 0,03 & 0,03 & 0,02 & 0,04 & 0,20 & 0,03 \\
$\quad$ Total & 1 & 1 & 1 & 1 & 1 & 1 & 6 & 1 \\
\hline
\end{tabular}

3) Making Consistency Ratios

This calculation is used to ensure that the consistency ratio $(\mathrm{CR})<=0.1$. If it turns out that the $\mathrm{CR}$ value is more than 0.1 , then the pairwise comparison matrix must be corrected. To calculate the consistency ratio, a consistency ratio table is made as shown in Table 3.

Table 3. Consistency ratios

\begin{tabular}{crrr}
\hline & $\begin{array}{c}\text { Total } \\
\text { Multiplication } \\
\text { Results }\end{array}$ & Priority & $\begin{array}{r}\text { Total= Multiplication } \\
\text { Results/Priority }\end{array}$ \\
\hline Fakir (FK) & 2,71 & 0,41 & 6,66 \\
Poor(MK) & 1,66 & 0,25 & 6,72 \\
Debt/ Gharimin (HG) & 1,09 & 0,17 & 6,45 \\
Parents of income (POT) & 0,57 & 0,09 & 6,37 \\
Dependents of parent (TOT) & 0,33 & 0,05 & 6,09 \\
\hline
\end{tabular}




\begin{tabular}{|c|c|c|c|}
\hline Criteria & $\begin{array}{r}\text { Total } \\
\text { Multiplication } \\
\text { Results }\end{array}$ & Priority & $\begin{array}{r}\text { Total }=\text { Multiplication } \\
\text { Results/Priority }\end{array}$ \\
\hline Parent's business/ work(UPOT) & 0,21 & 0,03 & 6,22 \\
\hline \multicolumn{3}{|c|}{ Total } & 38,51 \\
\hline
\end{tabular}

1) $\Lambda$ maks $=\frac{\text { Total }=\text { Multiplication Results/Priority }}{n}$

2) $\Lambda$ maks $=\frac{38,51}{6}=6,42$

3) $\mathrm{CI}=\frac{\Lambda \text { maks }-\mathrm{n}}{n-1}=\frac{6,42-6}{6-1}=0,08$

4) $\mathrm{IR}=1,24$

5) $\quad \mathrm{CR}=\frac{C I}{I R}=\frac{0,08}{1,24}=0,07$

After calculating with the AHP method, we get the weights of each criterion and subcriteria. Next, SAW method will do the calculation to rank the existing alternatives. The following manual calculations on the SAW method include the following:

1) The value was obtained by each candidate (using dummy data), can be seen in Table 4.

Table 4. Candidates for the Recipients of "Buleleng Cerdas" Social Funds

\begin{tabular}{lllllll}
\hline Alternatif & FK & MK & HG & POT & TOT & UPOT \\
\hline Sinta & Very & Middling & 10.000 .000 & 500.000 & 5 & Farmer \\
Yor & Middling & Middling & 500.000 & 100.000 & 1 & Fisherman \\
Rizal S & Very & Middling & 3.000 .000 & 650.000 & 7 & Employee \\
\hline
\end{tabular}

2) Value confirmation based on value range, the values in each of these criteria have been obtained from calculations using the AHP method which has a value of $\mathrm{W}=41 \%, 25 \%, 17 \%, 9 \%, 5 \%$ and $3 \%$. The following see Table 5 .

Table 5. Value Confirmation

\begin{tabular}{lllllll}
\hline Alternatif & FK & MK & HG & POT & TOT & UPOT \\
\hline Sinta & 0,59 & 0,22 & 0,12 & 0,15 & 0,23 & 0,26 \\
Yor & 0,22 & 0,22 & 0,12 & 0,26 & 0,12 & 0,26 \\
Rizal S & 0,59 & 0,22 & 0,23 & 0,15 & 0,65 & 0,15 \\
\hline
\end{tabular}

3) Making a decision matrix $X$, as below

$$
X=\left[\begin{array}{llllll}
0,59 & 0,22 & 0,12 & 0,15 & 0,23 & 0,26 \\
0,22 & 0,22 & 0,12 & 0,26 & 0,12 & 0,26 \\
0,59 & 0,22 & 0,23 & 0,15 & 0,65 & 0,15
\end{array}\right]
$$

4) Making Normalization of Decision Matrix R

Of all the attributes stated that the whole is a benefit. The following matrix below is the normalization of decision matrix $\mathrm{R}$. 


$$
\mathrm{R}=\left[\begin{array}{llllll}
1,00 & 1,00 & 0,52 & 0,58 & 0,35 & 1,00 \\
0,37 & 1,00 & 0,52 & 1,00 & 0,18 & 1,00 \\
1,00 & 1,00 & 1,00 & 0,58 & 1,00 & 0,58
\end{array}\right]
$$

5) The final result preference value (Vi) obtained from the number of normalized multiplied row $(\mathrm{R})$ row matrices weighs the appropriate preference element matrix (W) matrix. The following calculation of the final preference value, among others:

$$
\begin{aligned}
& \begin{aligned}
\mathrm{Vi}_{1}=0,41 * 1+0,25 * 1+0,17 * 0,52+0,09 * 0,58+0,05 * 1+ \\
0,03 * 1
\end{aligned} \\
& \quad=0,847 \\
& \begin{aligned}
\mathrm{Vi}_{2}= & 0,41 * 0,37+0,25 * 1+0,17 * 0,52+0,09 * 1+0,05 * 0,52+ \\
& 0,03 * 1=0,620 \\
\mathrm{Vi}_{3}= & 0,41 * 1+0,25 * 1+0,17 * 1+0,09 * 0,58+0,05 * 1+ \\
0,03 * 0,58 & \\
= & 0,948
\end{aligned}
\end{aligned}
$$

Then the final results are obtained from the candidates who are the recipients of the

"Buleleng Cerdas" social fund from the existing alternatives as follows:

1. Rizal $\mathrm{S}$ is in rank 1 ,

2. Sinta is ranked 2 nd, and

3. Yor is ranked 3 rd.

The implementation of manual calculations on the system as follows:

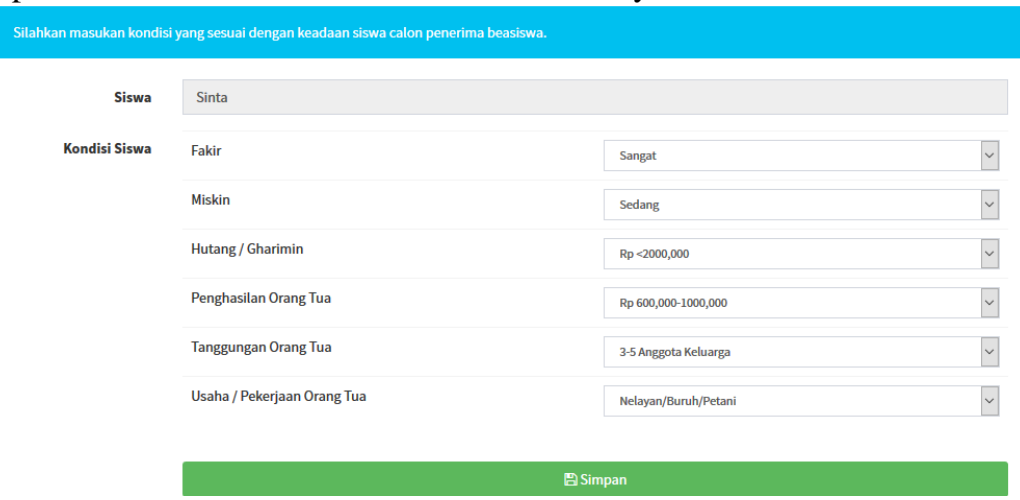

Figure 4. Implementation display of calculating student conditions 1 
Silahkan masukan kondisi yang sesuai dengan keadaan siswa calon penerima beasiswa.

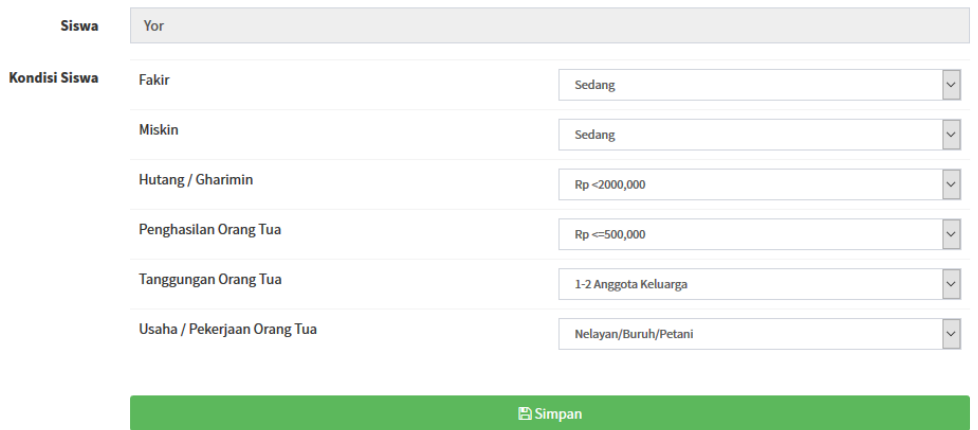

Figure 5. Implementation display of calculating student conditions 2
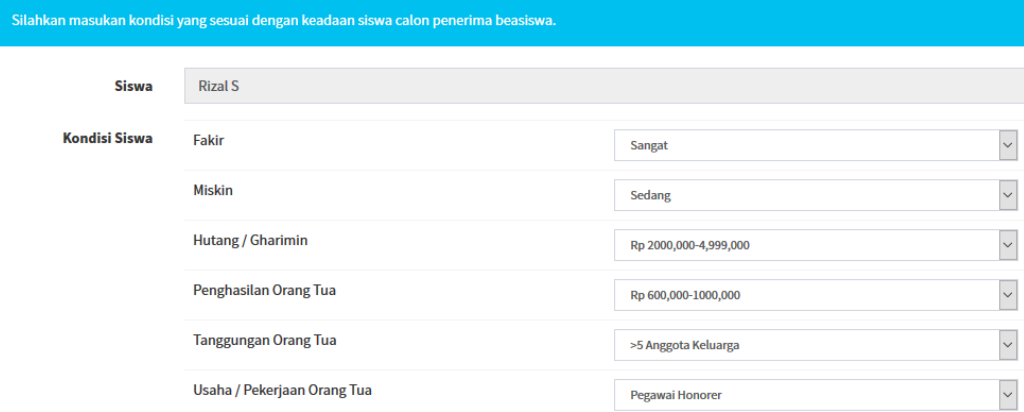

Figure 6. Implementation display of calculating student conditions 2

\section{Hasil Perangkingan}

Berikut merupakan daftar rekomendasi perangkingan berdasarkanjenis beasiswa.

\begin{tabular}{l|ll}
\multicolumn{2}{l}{ Bantuan Anak Didik } \\
Show $10 \quad \checkmark$ entries & & \\
No. & $\$ 1$ NISN & Nama Siswa \\
1 & 2340 & Rizal S \\
2 & 2002 & Sinta \\
3 & 2001 & Yor \\
\hline
\end{tabular}

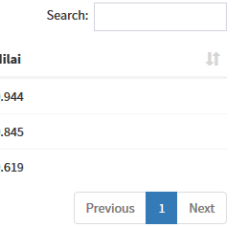

Figure 7. The implementation display of student recommendations/ranking results with AHP and SAW methods 
The output generated in the AHP and SAW processes is that there is a difference of 0.004 in Rizal S, 0.002 in Sinta and 0.001 in Yor. But the difference is not significant so the calculation is appropriate.

In general, software testing runs smoothly, both during black-box testing, whitebox testing, test UEQ user experience and suitability testing of manual calculations on the system. Based on the results of testing black box (functionality testing) obtained that the process run by the user has been able to run well. Then, based on the results of testing white box (procedural) obtained that the implementation of the algorithm has been successful. Furthermore, based on the user response test obtained the category Very Good with the results of user responses 93\% percentage. Furthermore, the user experience test results have a positive impression (value approaching 1 and so on) successively decreased in the Group of Attraction, Clarity, Efficiency, Accuracy, Stimulation, and Novelty. The last test of suitability testing of manual calculations on the system is appropriate.

\section{CONCLUSION}

The application of AHP and SAW methods for "Buleleng Cerdas" with many different criteria can be combined to produce recommendations for prospective recipients of social funds. As for suggestions for the future, this research can be further developed by combining other methods and different criteria to determine more effective recommendations.

\section{REFERENCES}

[1] Surya, C. (2015). Sistem Pendukung Keputusan Rekomendasi Penerima Beasiswa Menggunakan Fuzzy Multi Attribut Decision Making (FMADM) dan Simple Additive Weighting (SAW). Jurnal Rekayasa Elektrika, 11(4), 149-156.

[2] Iskandar, F. Soebroto, A. A. \& Regasari, R. (2013). Sistem Pendukung Keputusan Seleksi Beasiswa PPA dan BBM Menggunakan Metode Fuzzy AHP. Smatika Jurnal, 3(1), 2-11.

[3] A. W. Pamungkas, A. W., Nugroho, D., \& Siswanti, S. (2016). Sistem Pendukung Keputusan Penerimaan Beasiswa Kurang Mampu SMK Harapan Dengan Metode Simple Additive Weighting (SAW). Jurnal Teknologi Informasi dan Komunikasi (TIKomSiN), 4(1), 35-41.

[4] Mufizar, T., Anwar, D. S., \& Dewi, R. K. (2016). Pemilihan Calon Penerima Bantuan Siswa Miskin Menggunakan Metode Analytical Hierarchy Process (AHP). Creative Information Technology Journal, 4(1), 30-44.

[5] Saifulloh, S., \& Asnawi, N. (2015). Analisis Keakuratan Metode AHP dan Metode SAW Terhadap Sistem Pendukung Keputusan Penerimaan Beasiswa. Data Manajemen dan Teknologi Informasi (DASI), 16(3), 96-100.

[6] Jati, H. (2010). Decision Support System for Managing and Determining International Class Program: GA and AHP approach. Journal of Education, 3(01), 11-32. 
[7] Setyani, R. E., \& Saputra, R. (2016). Flood-prone Areas Mapping at Semarang City by using Simple Additive Weighting Method. ProcediaSocial and Behavioral Sciences, 227 , 378-386.

[8] Pressman, S. R. and Maxim, B. R. (2015). Software Engineering - A Practitioner's Approach - Eighth Edition. USA: Mc Graw Hill Education. 